\title{
バイオリファイナリーによる未利用資源や 産業廃棄物からの有用脂質生産 \\ Production of Valuable Lipids from Underutilized Resources and Industrial Wastes by Biorefinery System
}

\author{
渡邊 研志 \\ 広島大学 大学院統合生命科学研究科 \\ 干 739-8530 \\ 東広島市鏡山 1-3-1 \\ Kenshi WATANABE \\ Graduate School of Integrated \\ Sciences for Life, Hiroshima University \\ 1-3-1 Kagamiyama, Higashi-Hiroshima \\ 739-8530, Japan
}
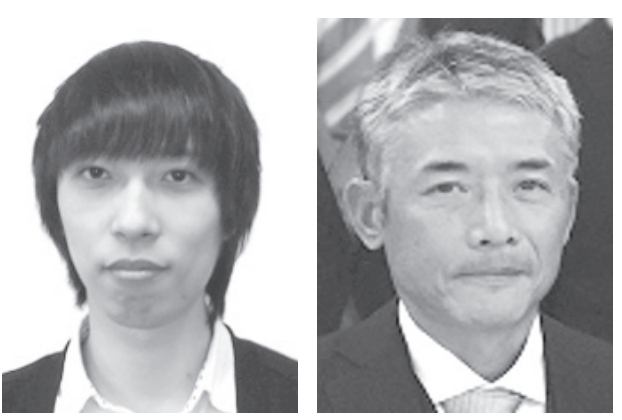

\author{
秋 庸裕 \\ 広島大学 大学院統合生命科学研究科 \\ 干 739-8530 \\ 東広島市鏡山 1-3-1 \\ Tsunehiro AKI \\ Graduate School of Integrated \\ Sciences for Life, Hiroshima University \\ 1-3-1 Kagamiyama, Higashi-Hiroshima \\ 739-8530, Japan
}

論文要旨：地球環境の保全と資源・エネルギーの再生利用を両立する持続的技術として, 海洋大型藻類や 火力発電排出ガスを原料としたバイオリファイナリーにより, 高度不飽和脂肪酸やカロテノイド, 炭化水素 などの有用脂質を生産する新規システムの構築を進めている。油糧微生物ラビリンチュラ類オーランチオキ トリウム属の有機酸資化性を活用した二段階発酵系とゲノム育種による高機能化を統合して生産性の最大化 をめざしているので，その進渉を紹介する。

\begin{abstract}
For conservation of the global environment with the recycling of resources and energy, a novel sustainable biorefinery system has been developed to produce useful lipids such as polyunsaturated fatty acids, carotenoids, and hydrocarbons from marine macroalgae and thermal power generation exhaust gas. To maximize the productivity, a two-stage fermentation system was constructed using oleagenous Labyrinthulean protist, genus Auranthiochytrium, assimilating organic acids, which was tried to further functionalize by genome breeding technologies.
\end{abstract}

Key words: biorefinery, macroalgae, greenhouse gas, carotenoids, polyunsaturated fatty acids

\section{1 はじめに}

近年, 世界的な人口やエネルギー消費量の増加に伴い, 地球環境の保全と天然資源の有効利用に資する新技術の 確立が喫緊の課題となっている。特に，石油や石炭など の化石資源に代わる再生可能エネルギーに期待がかけら れており，我が国でも，太陽光発電の高効率化や設備の 普及が進められるとともに, 風力や地熱, バイオマスな どを利用した発電技術も鋭意検討されている。しかし， 現時点での国内エネルギー需要に対する供給比率は合計 10 数\%程度に過ぎず，その伸び率を考慮しても当面は

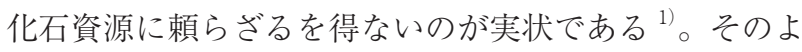
うな中, 火力発電の高効率化システムとして石炭ガス化

連絡者：秋庸裕

E-mail : aki@hiroshima-u.ac.jp
燃料電池複合発電技術 (Integrated coal gasification fuel cell combined cycle； IGFC）が実証段階に入っており, $\mathrm{CO}_{2}$ の分離 · 回収を組み合わせた革新的低炭素火力発電 の実現を射程範囲に捉えている。したがって, 再生可能 エネルギーの改良や開発を継続するとともに, 火力発電 で排出される $\mathrm{CO}_{2}$ の有効利用・貯留技術 (Carbon dioxide capture, utilization and storage）を確立することが, 「持続可能な開発目標（Sustainable development goals； SDGs）」の達成にも寄与する重要な課題と考えられる。

これらの課題に対して筆者らは, 微生物を触媒とした バイオリファイナリー技術の適用による解決をめざして いる。バイオリファイナリーは, 農作物の非可食部分や 間伐材などの未利用バイオマスあるいは食品製造残椬や 下水污泥などの廃棄物系バイオマスを原料に, 主に微生 物の物質変換能力を活用してバイオ燃料や化学品を生産 
する技術である。廃棄物の処理にかかるコストや環境負 荷を低減しながら, 有用物質へと再生する一挙両得の技 術であり，廃呆物を原料としたメタンやエタノールの発 酵システムがすでに実用化されている。バイオリファイ ナリーではまた, 原料も生産物も拡張可能である。本稿 でも後述の通り, 原料としては大型藻類や火力発電排出 ガスも有効であり，生産物としては健康食品や水畜産飼 料, コスメ製品, 医薬品などの素材となる高付加価值物 質も当然，視野に入る。こうした多様性は，基本的には 触媒となる微生物の代謝性能に依存する。薬剂処理や遺 伝子組換え技術による変異導入によって理想の代謝経路 に改変できれば良いが，大幅な改変は微生物細胞内での 物質・エネルギーバランスを乱すため，変換効率を下げ る原因にもなり得る。したがって，原料に対する資化性 や目的物質の生産性が高い野生株の獲得が開発研究の初 期段階での成否の鍵を握っている。

筆者らは以前から, 海洋性の油糧微生物ラビリンチュ ラ類オーランチオキトリウム (Aurantiochytrium) 属に 着目して，その利用技術の開発を試みてきた。ラビリン チュラはクロミスタ界の不等毛藻に属するが, 光合成能 を持たず，一般的な藻類とは異なる従属栄養型の真核単 細胞微生物である。高度不飽和脂肪酸であるドコサへキ サエン酸（DHA）の顕著な生産性から産業界で注目を集 めるとともに, 海洋における高い賦存量から海洋生態系 における重要な役割が想起され，環境生物学的にも興味 深い。筆者らは, DHAの新規供給源を探索する過程で, アスタキサンチンなどの抗酸化性カロテノイドやスクア レンなどのイソプレノイド炭化水素を共生産する新種株 を見出した ${ }^{2,3)}$ 。さらなる新規株の収集と系統分類に続き, 組成脂質の酵素化学的改変, 食品廃棄物を基質原料とす る利用法や分子育種に有用な形質転換法の開発を通じて, ラビリンチュラの脂質生合成・代謝系の理解と生産効率 化を進めてきた ${ }^{4-8)}$ 。その高密度培養による各種機能性脂 質の生産効率は，それらを各々生産する光合成藻類や細 菌類と比肩するレベルにある。DHA 生産系はすでに商用 化されており，サプリメントや水産飼料への応用では一 定の成果が認められるが，さらなる市場及び用途の拡大 に向けては一層の低コスト化が要望される。このような 背景から, 大型藻類を新たな原料としたバイオリファイ ナリーによる有用脂質生産系の開発に着手した。

\section{2 海藻糖質からのカロテノイド生産}

近年, 持続的低炭素社会の実現に向けて, エネルギー や有用物質の生産原料となる生物資源, すなわちバイオ マスの利用法の開発が世界的に益々活発になってきた。 当初は, とうもろこしなどの可食バイオマスが利用され
たが，食糧との競合による価格高騰が問題となった。次 に草本類がターゲットとなったが, セルロースやリグニ ンなど不溶性繊維の分解と可溶化のプロセスが未だ課題 として残されている。これらの陸上植物と比べて水産バ イオマスは利用形態の自由度が高く, 生産性, 賦存量, 炭素貯蔵量も比較的高いことから注目され始めた。なか でも，大型藻類は海洋国家である我が国にとって潤沢な 再生可能資源であり，有効活用が望まれる。

筆者らを含む広島大学研究グループは, 2012 年から 科学技術振興機構 - 戦略的創造研究推進事業「藻類 - 水 圈微生物の機能解明と制御によるバイオエネルギー創成 のための基盤技術の創出」において, CREST 事業「海 洋微生物発酵制御を基盤とした大型藻類の完全資源化基 盤技術の開発」を推進してきた。本事業では, 大型藻類 を完全資源化するために適した海洋微生物の取得と発酵 生産システムの構築をめざし, 高塩濃度条件に馴化した 海洋污泥菌叢によるメタン発酵技術を中心に, 大型藻類 原料の水熱処理による可溶化技術や発酵残椬からの希少 元素の回収技術など, 各種要素技術の確立を進めてきた (Fig. 1)。筆者らの研究チームが担当したラビリンチュ ラ類による高付加価值脂質生産は，これらのエネルギー 生産プロセスを経済収支において支援するとともに, 当 微生物の新たな活用法を開発する目的で実施した。

\section{$2 \cdot 1$ 褐藻マンニトールの原料化}

海洋大型藻類は褐藻, 紅藻, 緑藻の三種類に大別され, 賦存量は褐藻が圧倒的に多い。褐藻はラビリンチュラと 同じくクロミスタに属する不等毛藻だが多細胞体であ り, コンブやワカメ，ホンダワラがその代表例である。 光合成色素と受光波長の関係で海面から深い位置に生育 するため, 栽培や収穫には工夫が必要となるが, 生産速 度の高さから経済性の担保が期待できる有望なバイオマ スである。大型藻類に含まれる主な糖質成分としては, アルギン酸，マンニトール，フコイダン，ラミナランな ど, 淡水藻類や陸上植物には見られないものが多い。そ こで，ラビリンチュラ類オーランチオキトリウム属株の 資化性を調べたところ，それらの糖質を直接利用できな いことが分かった。一方，グルコースやガラクトース， フルクトース，マンノース，グリセロールなどの単糖で あれば，顕著に増殖した。したがって，海藻糖質をこれ らの単糖に変換する前処理技術が必要となる。水熱処理 による多糖の低分子化は別途試行中であり, 酵素製剤な どのコスト的に不利な選択肢を避けて, 微生物変換の可 否を検討することにした。

近海から単離した微生物や海藻糖質に対する資化性が 報告あるいは予想された系統保存株の培養上清を炭素源 として, オーランチオキトリウム属株の増殖性を調べ 


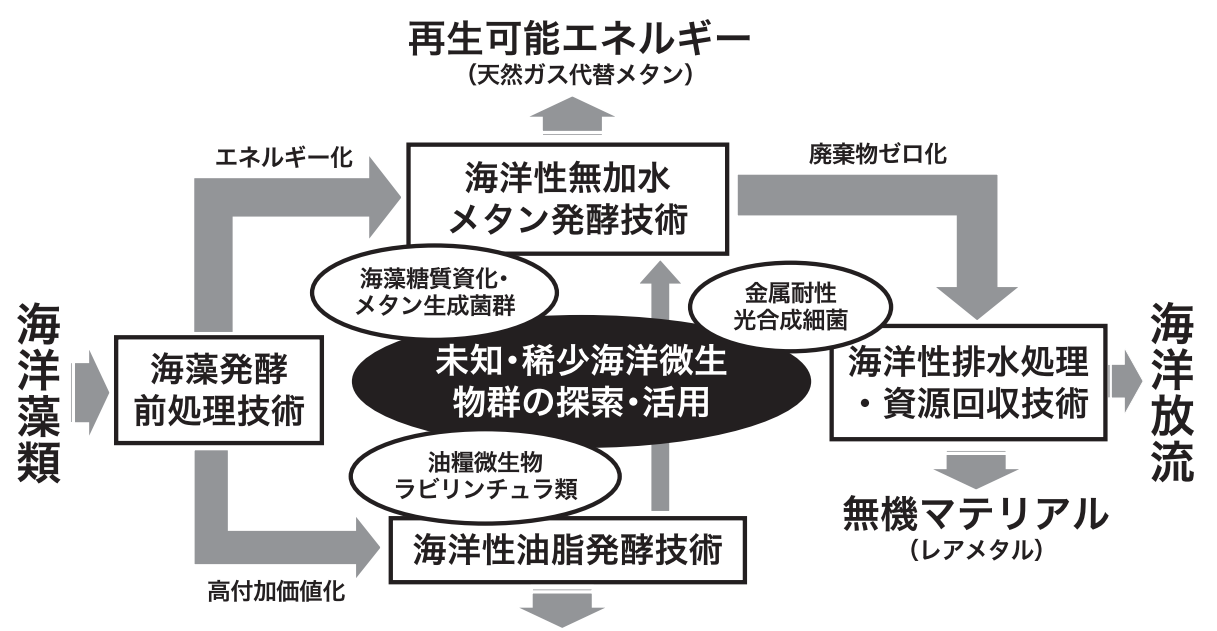

有機マテリアル

(不飽和脂質、カロテノイド、峞化水素)

Fig. 1 海洋微生物発酵制御を基盤とした大型藻類の完全資源化基盤技術の開発
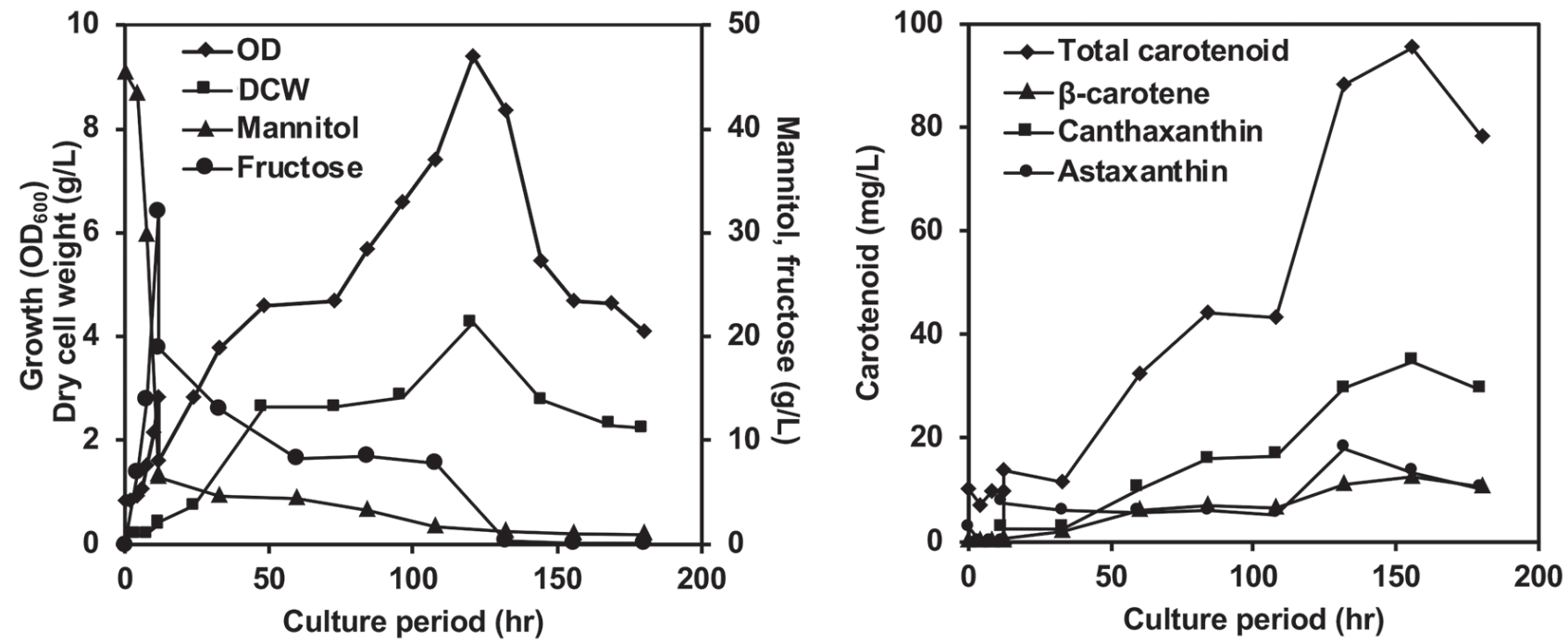

Fig. 2 二段階培養による海藻糖質からのカロテノイド生産

グルコノバクター属 NBRC14819 株を $10 \mathrm{~g} / \mathrm{L}$ ポリペプトン, $5 \mathrm{~g} / \mathrm{L}$ 酵母エキス, pH6.0 を含むコンブ抽出液 $3 \mathrm{~L}$ （100 g/L 乾燥昆 布からの水抽出，遠心上清）で $28^{\circ} \mathrm{C}, 12$ 時間培養した後， $2 \%$ 人工海水 $3 \mathrm{~L}$ を加え，オーランチオキトリウム属 $\mathrm{KH} 105$ 株を接種 して培養を継続した。

た。その結果，褐藻などの主要糖質であるマンニトール （固形分の 10～30 wt％）を，オーランチオキトリウム 属株が資化できるフルクトースに変換して細胞外に遊離 する好気性酢酸菌グルコノバクター（Gluconobacter） 属が有望株として得られた ${ }^{9)}$ 。グルコノバクター属菌の ペリプラズム画分に存在するソルビトール脱水素酵素に よる変換反応で, 細胞への取り込み量を超えて生成した フルクトースが培地中に遊離したと考えられた。グルコ ノバクター属菌は，オーランチオキトリウム属株の至適 濃度である $2 \%$ 以上の海水塩存在下でほとんど生育しな かった。したがって, 褐藻（コンブ）から水抽出したマ ンニトールを主たる炭素源として, グルコノバクター属 菌によるフルクトースへの糖質变換反応の後, 海水塩の
添加による制菌とオーランチオキトリウム属株の接種に より，フルクトースを基質として有用脂質を生産する二 段階培養システムが成立した（Fig. 2)。海藻バイオマス とオーランチオキトリウム属をつなぐ発酵生産系はこれ が最初の例である。食品や化粧品素材として需要が高 まっているアスタキサンチンについて, 海藻原料の単位 重量あたりの生産性と市場価格を参照し, メ夕ン発酵系 の物質収支と合算したところ，エネルギー収支と経済収 支を両方同時にプラスにしうる原料分配比が明らかとな り，その実用性を示すことができた。

\section{$2 \cdot 2$ アルギン酸の利用とその展開}

アルギン酸も褐藻の主要糖質であり, マンニトールと 同等かそれ以上の組成率を示すことから発酵基質として 
無視できない。そこで，アルギン酸資化性の海藻付着微 生物や系統保存株とオーランチオキトリウム属を組み合 わせた共培養の系を検討したが，得られた候補微生物で は増殖及び脂質生産性が不十分であった。一方，上記事 業の共同研究者らによって，アルギン酸原料でのメタン 発酵でその分解に関与するジスゴ)モナス (Dysgonomonas）属株が海洋沿岸污泥から単離された ${ }^{10)}$ 。その培養 上清を含む培地でオーランチオキトリウム属株の顕著な 増殖が見られ，アルギン酸を基質原料とした油脂生産が 可能であることが実証された。ジスゴノモナス属は海洋 における一次分解者として知られており，この組み合わ せで生態系の一部が再現できている可能性もある。しか し，両微生物間に介在する物質は当初不明であった。そ こで，ジスゴノモナス属株の主要生成物である各種有機 酸に対するオーランチオキトリウム属株の資化性を調べ たところ，特定の株においては酢酸やクエン酸などが一 定の濃度及び pH の範囲内で有効な炭素源となりうるこ とが分かった（Fig. 3）。

褐藻の属種によっては, マンニトールとアルギン酸で 固形分の $60 \%$ 以上を占めるため, 海洋での賦存量とし ては最も高い糖質の新規利用法を開発したとも言える。 ただし，生産効率や対糖収率などの発酵指標は未だ改善 の余地がある。現在, 糖質代謝や脂質生合成の各経路を
至適化する個別戦略とオミクス技術の適用による俯瞰的 攻略の両面から解決を図っているところである。また, 実用化に際して必要となる連続あるいは反復培養の実現 に向けた検討も続けている。

\section{3 火力発電排出ガスからの油脂生産}

火力発電の高効率化に向けては IGFC を始め, 実証レ ベルの新技術が検討されているところだが，分離・回収 された排出 $\mathrm{CO}_{2}$ の再利用, すなわちカーボンリサイク ルは各種技術が提案, 比較される段階にある。微細藻類 による炭素固定及び有用物質生産はその有力候補の一つ であり，その炭素固定に要するエネルギー源として太陽 光が十分に利用できる環境では有望な技術となる。現状 では, エネルギー変換効率を格段に向上させて増殖速度 を上げる必要があるが, その結果, 細胞密度と光照射効 率の両立がさらなる問題となって立ちはだかる。

一方，筆者らは，非光合成型の従属栄養微生物である オーランチオキトリウム属の有機酸に対する高い資化性 をこの目的に適用する方法として， $\mathrm{CO}_{2}$ を還元固定化し て酢酸を遊離生成するホモ酢酸菌と組み合わせた二段階 培養システムを提案している ${ }^{11,12)}$ 。ホモ酢酸菌は, メ タン発酵系において基質生体高分子の代謝分解で生成す る $\mathrm{CO}_{2}$ から酢酸を合成してメタン菌に供給する役割を果
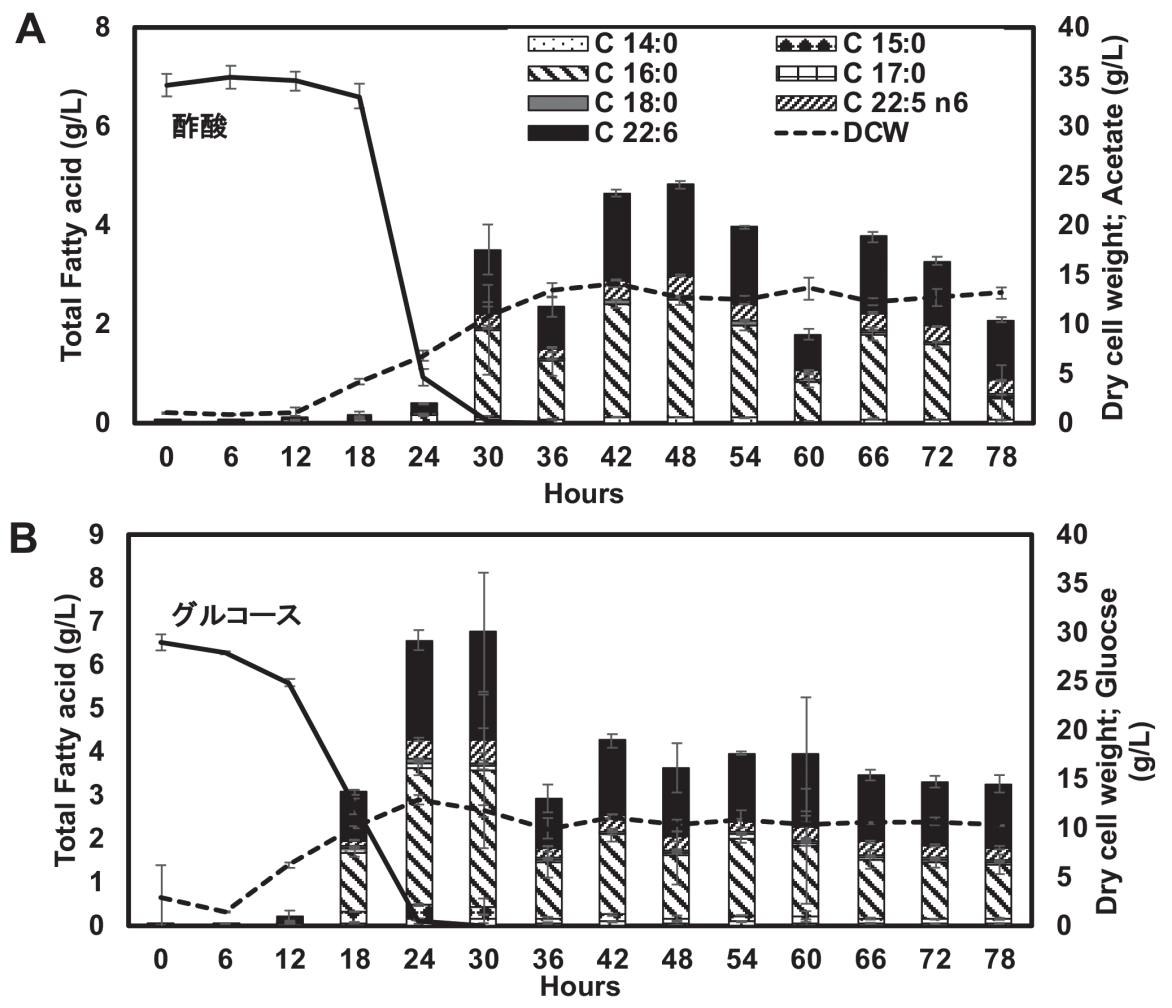

Fig. 3 酢酸を炭素源としたオーランチオキトリウム属による油脂生産 オーランチオキトリウム属 SR21 株を $30 \mathrm{~g} / \mathrm{L}$ 酢酸（A）またはグルコース（B），6g/L ポリペプトン， $2 \mathrm{~g} / \mathrm{L}$ 酵母エキス，20 g/L 人工海水塩（pH6.5）を含む培地で $28^{\circ} \mathrm{C} ， 150 \mathrm{rpm}$ にて培養した。 


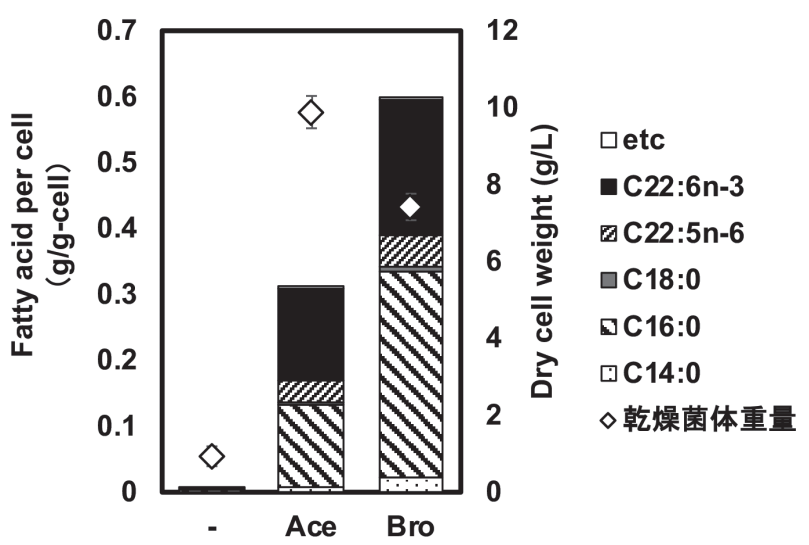

Fig. 4 二段階培養による $\mathrm{CO}_{2}$ からの脂肪酸生産 ホモ酢酸菌 Acetobacterium woodii DSM1030 の培養用培地 (-), 同培地に $30 \mathrm{~g} / \mathrm{L}$ 酢酸を添加した培地（Ace）及び, 同培地での $\mathrm{CO}_{2}$ 存在下での培養後の回収液 (Bro, $29.3 \mathrm{~g} / \mathrm{L}$ 酢酸を含む）にそれぞれ Aurantiochytrium limacinum SR21 株を接種して， $28^{\circ} \mathrm{C} ， 250 \mathrm{rpm} に て 48$ 時間培養した。

たす。ホモ酢酸菌において, $\mathrm{CO}_{2}$ から Wood-Ljungdahl 経路を通じて生成するアセチル CoA は細胞構築素材と して利用されるとともに，一部が分解されて ATP とし て生体エネルギーを得る。このとき, 酢酸だけを最終生 成物として排出することからアセトゲンとも呼ばれてお り，アセトバクテリウム (Acetobacterium) 属, モレラ (Moorella) 属やクロストリジウム (Clostridium) 属な どが分類される嫌気性微生物の一群である。

実際に， $\mathrm{CO}_{2}$ を主たる炭素源とする嫌気条件下でアセ トバクテリウム属株を培養し, 得られた䣷酸含有培養液 をほぼそのまま第二段階の培地としてオーランチオキト リウム属株を接種したところ, 顕著な細胞増殖と脂肪酸 生産が認められた（Fig. 4）。培養前のアセトバクテリウ 厶用培地に同等濃度の酢酸標品を添加した合成培地で オーランチオキトリウム属株を培養した場合と比較する と, 窒素源濃度が 1 段目で消費された分だけ増殖量は 20\%程度低かったが，細胞あたりの脂肪酸含有率は約 2 倍であった。この結果は，オーランチオキトリウム属株 の増殖や脂質生産を阻害する物質がアセトバクテリウム 属株によって生産されておらず，今後の条件至適化によ る生産性の向上が期待できることを示している。現在, 各ステップの培養特性を詳細に解析して, 連続あるいは 半連続培養系を連結した高効率 Gas-to-Lipids バイオプ ロセスを構築しているところである（Fig. 5)。

\section{4 オーランチオキトリウム属のゲノム育種による生産 脂質の改質}

発酵原料の多様化とともに，生産物の多量化及び多様 化も進めている。オーランチオキトリウム属は高度不飽 和脂肪酸やカロテノイドなどの高付加価值脂質を野生株

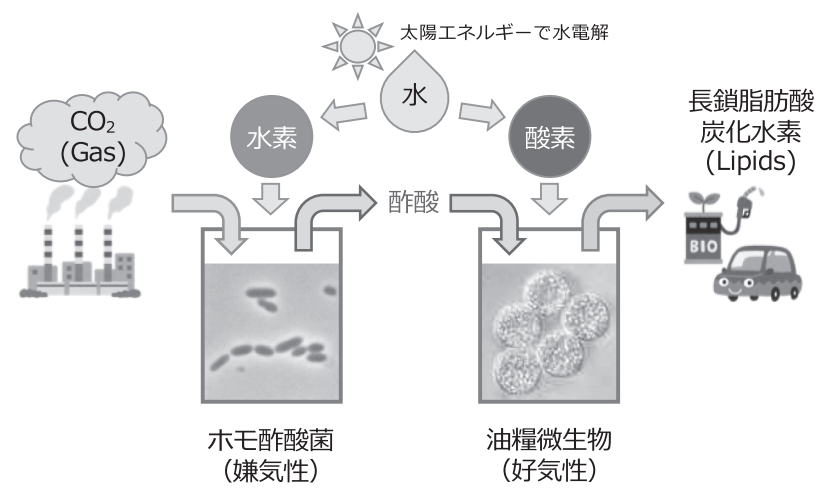

Fig. 5 カーボンリサイクルを実現する Gas-to-Lipids バイオ プロセス

でも顕著に生産するが, さらなる生産性改善のために遺 伝子への変異導入や人為的改変による特定成分の増産や 組成改質が行われている。

筆者らは，食品用途に利用可能な突然変異誘発法によ り, アスタキサンチンやカンタキサンチンなどの抗酸化 性カロテノイドの高生産株を取得した ${ }^{13)}$ 。すなわち, オー ランチオキトリウム属の遊走子に対して遺伝子変異誘発 剤としてニトロソグアニジンを暴露し, 固体培地上でカ ロテノイドに由来する赤橙色をより強く呈するコロニー を単離した。一例としては, $0.3 \mathrm{mg} / \mathrm{L}$ 程度の $\beta$ - カロテ ンを生産する野生株への複数回の変異誘発処理により, 総カロテノイド生産量としてそれぞれ $22 \mathrm{mg} / \mathrm{L}$ 及び 43 $\mathrm{mg} / \mathrm{L}$ を示す変異株 RH-7A と RH-7A-7が順次得られた。 いずれも $\beta$ - カロテンからアスタキサンチンに至る生合 成経路上の 5 種類のカロテノイドが生産されていたこと から, 遺伝子変異はその上流で働く $\beta$-カロテン合成酵 素 CrtIBYの発現に関わる部位やその基質生成に関わる 遺伝子に導入されたことが推察された。さらにこれら 変異株のメタボローム解析で, 酸化ストレス応答に関わ る因子の変動が見られたため，酸化ストレスを誘導する 鉄イオンを添加して培養したところ, 抗酸化活性が特に 高いアスタキサンチンの含有率が顕著に増加した。

近年，多くの生物種の育種においてゲノム編集技術が 適用されるようになった。部位特異的に作用する人工又 クレアーゼを利用して標的遺伝子のノックアウトあるい は外因性遺伝子のノックインを行う技術である。なかで も CRISPR-Cas9 システムが簡便であり, Cas9 ヌクレアー ゼとそれを標的部位に誘導する guide RNA との複合体 をあらかじめ形成して細胞に導入すれば，外因性遺伝子 の残存がない限り，薬剤変異導入と同様に食品用途にも 利用可能とされている。筆者らは，ゲノムワイドなスク リーニングを目的として，オーランチオキトリウム属へ の CRISPR-Cas9 システムの適用を試みた。その際, $\beta$ カロテン合成酵素 CrtIBY を標的として，その失活によ 
りカロテノイドに由来するコロニーの赤橙色が白色にな ることを指標とした ${ }^{14)}$ 。単離株の DNA 塩基配列を解析 したところ，CRISPR-Cas9による改変の形跡が認めら れた。さらに, マーカー遺伝子のノックインにも成功し, 任意の遺伝子を標的とした機能解析を迅速に行う技術が 確立できたので，順次解析を進めており，ゲノム育種に よる実用株の樹立に向けて研究推進中である。

\section{5 おわりに}

異なる代謝特性を示す複数の微生物を組み合わせた物 質変換システムにより, 未利用資源として海洋大型藻類 を，また，産業廃棄物として火力発電排出 $\mathrm{CO}_{2}$ をそれ ぞれカロテノイドや脂肪酸に作り変える技術について概 略を述べた。二段階発酵は清酒醉造を始めとする古典的 な技術であるが，利用する微生物の組み合わせによって 原料と生産物の選択肢を増やせる柔軟性が強みである。 グルコノバクター属菌には多様な酸化還元酵素が細胞膜 に局在しているため, マンニトールの他にも多彩な原料 に対応できる。また, ホモ酢酸菌は草本類リグノセルロー スが資化可能であるなど，極めて多様なバイオマスを原 料化できることから，酢酸を介したオーランチオキトリ ウム属との複合発酵系でバイオ燃料や化学品を生産する バイオリファイナリー技術がさらに多角的に展開してい くことが期待される。

本研究を行うにあたり, 広島大学大学院統合生命科学 研究科. 中島田豊教授, 岡村好子准教授, 田島誉久助教, 山本卓教授, 同工学研究科 - 松村幸彦教授, 長瀬産業株 式会社・松山恵介氏, 出光興産株式会社 · 黛新造氏, 福 永哲也氏, 伊藤真治氏, 中国電力株式会社 - 沢田健氏, 角田祐介氏ならびに各研究グループ諸氏の多大な支援を 得ており，ここに感謝の意を表します。

\section{文 献}

1）経済産業省資源エネルギー庁。平成 30 年度エネルギー に関する年次報告（2019）。

(Agency for Natural Resources and Energy, Ministry of Economy, Trade and Industry. The Cabinet Approves the FY 2018 Annual Report on Energy (Japan's Energy White Paper 2019))

2) Aki, T.; Hachida, K.; Yoshinaga, M.; Katai, Y.; Yamasaki, T.; Kawamoto, S.; Kakizono, T.; Maoka, T.; Shigeta, S.; Suzuki, O.; Ono, K. Thraustochytrid as a potential source of carotenoids. J. Am. Oil Chem. Soc., 80, 789794 (2003).

3) Li, Q.; Chen, G. Q.; Fan, K. W.; Aki, T.; Jiang, Y. Screening and characterization of squalene-producing thraustochytrids from Hong Kong mangroves. J. Agric. Food
Chem., 57, 4267-4272 (2009).

4) Huang, J.; Aki, T.; Yokochi, T.; Nakahara, T.; Honda, D.; Kawamoto, S.; Shigeta, S.; Ono, K.; Suzuki, O. Grouping newly isolated docosahexaenoic acid-producing thraustochytrids based on their polyunsaturated fatty acid profiles and comparative analysis of $18 \mathrm{~S}$ rRNA genes. Mar. Biotechnol., 5, 450-457 (2003).

5) Huang, J;; Aki, T.; Kawamoto, S.; Shigeta, S.; Ono, K.; Suzuki, O. Enzymatic preparation of glycerides rich in docosahexaenoic acid from thraustochytrid single cell oils by Candida rugosa lipase. J. Oleo Sci., 51, 447-455 (2002).

6) Iwasaka, H.; Aki, T.; Adachi, H.; Watanabe, K.; Kawamoto, S.; Ono, K. Utilization of waste syrup for production of polyunsaturated fatty acids and xanthophylls by Aurantiochytrium. J. Oleo Sci., 62, 729-736 (2013).

7) Yamasaki, T.; Aki, T.; Mori, Y.; Yamamoto, T.; Shinozaki, M.; Kawamoto, S.; Ono, K. Nutritional enrichment in larval fish feed with thraustochytrid producing polyunsaturated fatty acids and xanthophylls. J. Biosci. Bioeng., 104, 200-206 (2007).

8）小埜和久, 秋庸裕, 河本正次. 特許第 4796787 号 (2006). (Ono, K. et al. Jpn. Pat. 4796787 (2006).)

9) Arafiles, K. H. V.; Iwasaka, H.; Eramoto, Y.; Okamura, Y.; Tajima, T.; Matsumura, Y.; Nakashimada, Y.; Aki, T. Value-added lipid production from brown seaweed biomass by two-stage fermentation using acetic acid bacterium and thraustochytrid. Appl. Microbiol. Biotechnol., 98, 9207-9216 (2014).

10) Kita, A.; Miura, T.; Kawata, S.; Yamaguchi, K.; Okamura, Y.; Aki, T.; Matsumura, Y.; Tajima, T.; Kato, J.; Nakashimada, Y. Dysgonomonas alginatilytica sp. nov., a novel alginate-degrading bacterium isolated from microbial consortium. Int. J. Sys. Evol. Microbiol., 65, 3570-3575 (2015).

11）秋庸裕, 渡邊研志, 中島田豊, 松村幸彦, 岡村好子, 田島誉久, 廣谷蘭, 石垣元務, 黛新造, 吉田和広, 沢 田健，角田祐介。特願 2017-250129（2017）。

(Aki, T. et. al. Jpn. Pat. Appl. 2017-250129 (2017).)

12) Perez, C. M. T.; Watanabe, K.; Okamura, Y.; Nakashimada, Y.; Aki, T. Metabolite profile analysis of Aurantiochytrium limacinum SR21 grown on acetate-based medium for lipid fermentation. J. Oleo Sci., 68, 541-549 (2019).

13) Watanabe, K.; Arafiles, K. H. V.; Higashi, R.; Okamura, Y.; Tajima, T.; Matsumura, Y.; Nakashimada, Y.; Matsuyama, K.; Aki, T. Isolation of high carotenoid-producing Aurantiochytrium sp. mutants and improvement of astaxanthin productivity using metabolic information. J. Oleo Sci., 67, 571-578 (2018).

14）北堀智希, 渡邊研志, 青井真人, 畑浩介, 高橋宏和, 岡村好子, 松山恵介, 黛新造, 秋庸裕. 第 71 回日本生 物工学会大会卜ピックス集, pp. 2-3 (2019).

(Kitahori, T. et al. The 71st Annual Meeting of the Society of Biotechnology of Japan, Abstracts. pp. 2-3 (2019).) 